\title{
Impacts of Job Resources on Nurses' Performance Working in Public Sector Hospitals
}

\author{
Rabiul Islam and Abdullah Mohammad Al-Homayan \\ School of Economics, Finance and Banking, UUM College of Business, 06010 UUM, Sintok, Kedah, Malaysia
}

Received 2013-08-04, Revised 2013-08-27; Accepted 2013-08-29

\begin{abstract}
Job resources refers to the physical, psychological, social or organizational aspects of the job which are necessary in the achievement of goals and objectives, necessary for the reduction of the negative effects of job demands including the associated psychological and psychological costs and which promote personal growth, learning and development. The aim of the study is to analysis the impacts of job resources on nurses' performance working in public hospitals. In order to achieve the study objective, a survey conducted. Questionnaires distributed to the public sector hospital's manager in Saudi Arabia. The findings of the study turn out to be true; the study will contribute to both theory and practice. Through the present study, the researcher expects the findings to shed light on the research conducted regression to analysis the impacts of job resources on nurses' performance.
\end{abstract}

Keywords: Job Resource, Nurse, Performance, Public Hospital

\section{INTRODUCTION}

\subsection{Job Resources}

The term job resources refers to the physical, psychological, social or organizational aspects of the job which are necessary in the achievement of goals and objectives, necessary for the reduction of the negative effects of job demands including the associated psychological and psychological costs and which promote personal growth, learning and development (Van Emmerik et al., 2009). It is also conceptualized as a kind of energetic reservoir in the work environment that can be tapped when the individual has to cope with job demands (De Jonge and Dormann, 2006). In this study, job resources are located within the job characteristics model that identifies a number of job characteristics that are salient in a nurse's job. They are feedback, skill variety, task significance and task identity (Bakker and Demerouti, 2007). In addition, job security is also pertinent given the context in the Kingdom of Saudi Arabia that employs a large number of foreign nurses. In this situation, job security is a pertinent issue for this group of nurses especially in the light of Saudization policy (refer to chapter two for this policy).

\subsection{Skill Variety}

Skills variety, as the name suggests, refers to the incorporation of various skills and talents in the course of undertaking work which is thought to create motivation and establish meaningfulness by eliminating boredom among the employees (Mehta and Shah, 2005). Hackman and Oldham (1980) define skill variety as the level to which the job needs different activities to fulfil it and it needs a person with a number of various skills and talents. Skill variety is considered as the idea that a work possesses and can use different kinds of skills in doing job (Graham, 2009). Owing to nursing profession as a job that requires a variety of skills that nurses must have at UUM College of Business, 06010 UUM, Sintok, Kedah, Malaysia 
work, this study defines skill variety as the different skills and talents that all nurses must obtain in order to perform their tasks and duties successfully.

As far as studies about skills variety are concerned, there have been very little that have concentrated on the skills variety by itself and even fewer that have looked at this aspect in health care settings least of all nursing (Kinnunen et al., 2008) in particular in the healthcare setting in the Middle East and Asia. But Bono and Judge (2003) demonstrated the mixture of skills among nurses operating the National Health Service direct line in the UK. The direct line is a telephone service that is available for $24 \mathrm{~h}$ of everyday reaching about $60 \%$ of the people of England (Schmidt and Hunter, 1998).

\subsection{Task Significance}

Task significance is another aspect of meaningful work in the Hackman and Oldham's job characteristic model which promotes motivation among employees. Also, it is one of the components in the Job Diagnostic Survey at the task level of job resources (Bono and Judge, 2003). It is referred to as the extent to which a job is important to people in the community as well as people in the organization (Mehta and Shah, 2005). In other words, task significance refers to the extent the job has an influence on the lives of other people, whether they are in the immediate organization or living in the world at large (Hackman and Oldham, 1980). Fullagar and Kelloway (2009), agreed that when employees feel that their jobs are insignificant, this can negatively influence their performance. Task significance involves both internal significance (i.e., how important the task is to the organization) and external significance (i.e., how proud employees are to tell their relatives, friends and neighbours what they do and where they work) (Garg and Rastogi, 2006). Lin and Hsieh (2002) found that if the employees feel that the task they are doing is significant, they will perform at their full efforts.

\subsection{Task Identity}

Mehta and Shah (2005) described task identity as the visible outcome of completing a task from the beginning to the end, which is very important for job satisfaction. Also, it refers to whether the job has an identifiable beginning and end or how complete a module of work the employee performs (Garg and Rastogi, 2006). It may function as initiators of a process that leads to work engagement and performance (Bakker and Demerouti, 2007).

Task identity is similar to task significance in a way that it refers to broader perspectives of work and whether the job has an impact on other people's lives and the extent to what the job entails. Performance has always been linked to individual activities in specific, isolated activities that do not have to have an impact on anyone besides the doer of the task. In the end, employees will perform flawless tasks when the tasks are first identified to them (Fullagar and Kelloway, 2009).

Task identity is one of the characteristics of the job characteristic model that is associated with personal growth and development among employees besides enabling them to achieve their goals and objectives while at work (Erez and Judge, 2001). Provision of employees with opportunities to maximize the use of their talents and abilities in the course of working towards achieving clear goals and objectives, they are more likely to perceive the job as being critical in the fulfilment of their personal goals as well.

\subsection{Feedback}

Feedback is a part of Hackman and Oldham job characteristics model (Goldenhar et al., 2001). It enables employees to have knowledge of the outcomes of the work that they have undertaken or how successful that they have been in converting their efforts into performance. Feedback is defined as the process where the output part of the system is returned back to the input for more effective output. It refers to objective information about progress and performance brought about from the job itself, from supervisors or from any other information system (Garg and Rastogi, 2006). In other words, job feedback is defined as the direct communication that an employee receives about the task after it is completed (Graham, 2009).

Job feedback can be received from the customer, co-workers or managers and whether it is positive or negative, it needs to be communicated to the performer of the task at a suitable time (Graham, 2009). In performance feedback, jobs differ in the amount and quality of feedback about performance (Bakker and Bal, 2010). Generally, job feedback directs employees to the big picture so that they can 
perform tasks better (Bowen and Lawer, 1992). Further, it aids the employees in developing a sense of meaning and purpose of working (Conger and Kanungo, 1988). It is one of the many windows of opportunities for employees to develop and grow their career growth (Mikkelsen et al., 2000) and prevent work problems (Bakker and Demerouti, 2007). As an intrinsic resource (Bakker et al., 2003), performance feedback is very important, which is a part of job resources (Demerouti et al., 2000).

\subsection{Job Security}

Job insecurity has been recognized as a chronic condition affecting the general workforce in this digital age (Ito and Brotheridge, 2007). According to Ito and Brotheridge (2007), job insecurity concerns not only with the potential loss of employment but also with the uncertainty regarding job and career issues including one's level of responsibility anad promotional opportunities. Besides, globalization and continuous international pressure on organizations to perform better with fewer resources are reflected in the changing psychological contracts between employers and employees (Rothmann and Joubert, 2007). Particularly, employees are expected to give more in terms of time, effort, skills and flexibility, whilst job security, career opportunities and lifetime employment are diminishing (Rothmann and Joubert, 2007).

The importance of job-security lies in its critical influence on work-related outcomes (Yahaya et al., 2010). For instance, a high level of job security means the employee would have a small chance of becoming unemployed. Furthermore, it is one of the most important factors that impacts job performance (Borg and Elizur, 1992), which leads studies to link job insecurity with psychological reactions such as low self-esteem and self-confidence and ultimately low performance (Wiley, 1997). Researchers tend to compare job security with job insecurity. Job insecurity is defined as perceived threat or reality of job termination or layoff faced by workers (Lee et al., 2008). In addition, it refers to the amount of uncertainty a person has about his or her job continuity or continuity of certain aspects of the job (Lim and Teo, 2000). The effects of lack of job security for nurses are the same as the effects for lack of job security among any other employees such as anxiety, depression, stress, burnout, poor health and poor sleep (Mikkelsen et al., 2000).

\section{MATERIALS AND METHODS}

The theoretical relationship between job resources and nurses' performance can be schematically diagrammed as shown in Fig. 1. The first independent variable in the present study is job resources which comprise five factors namely skill variety, task performance, task identity, feedback and job security. The dependent variable is nurses' performance. In brief, as shown in Fig. 1, job demands are expected to produce a response from employees at work such that job demands will make employees feel stressful but job resources will decrease job stress. For instance, the more demanding their job is, the more likely they will be experiencing work stress. However, when employees perceive that their job is interesting and challenging, the less stress they will experience.

\subsection{Pilot Study}

A pilot study can be described as a small-scale project that culls data from respondents that are similar to the target respondents of the study (Zikmund et al., 2010). It normally serves as a guide to the researcher for his/her actual larger study or to examine the ambiguous aspects of the research to find out whether the procedures will work as intended. In other words, pilot studies are important because they refine survey questions and reduce flaws in the study (Zikmund et al., 2010). Furthermore, the pilot study's importance lies in the fact that it improves the questionnaires (Neuman, 1997). Normally, the size of the pilot study ranges from 25-100 subjects (Cooper and Schindler, 2008).

The researcher examined the questionnaire instruments' reliability. The present study suggested that the threshold of an acceptable level of reliability is at least 0.70, according to Hair et al. (2010); Nunnally (1978) and Zikmund et al. (2010), in which a reliability estimate of 0.7 or higher suggests a good reliability. Table 1 shows the Cronbach's alpha values of the variables used in pilot study. As shown, the alpha values ranged from 0.773 to 0.943 . These values were higher than the threshold value of 0.70 , indicating that the instruments used to measure the main variables were reliable. 
Job resources

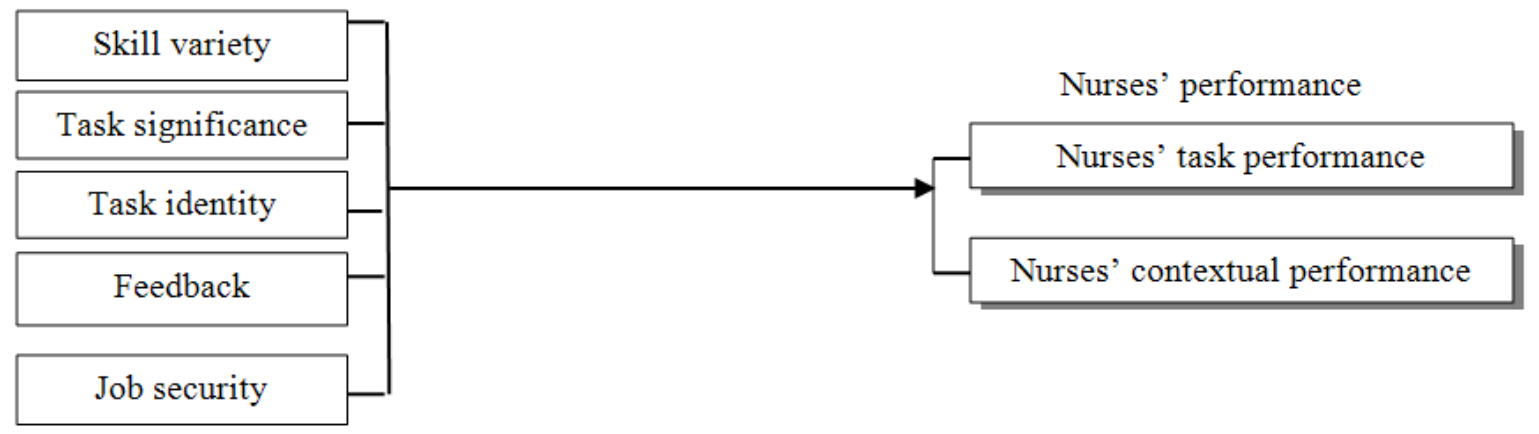

Fig. 1. Theoretical framework

Table 1. Result of cronbach's alphas of the main variables in pilot study

\begin{tabular}{llr}
\hline Number of items & Variables & Alpha \\
\hline 4 & Skill Variety (SV) & 0.801 \\
3 & Task Significance (TS) & 0.828 \\
3 & Task Identity (TI) & 0.828 \\
3 & Feedback (FB) & 0.773 \\
6 & Job Security (JSec) & 0.882 \\
23 & Nurses' Task Performance (NTP) & 0.943 \\
18 & Nurses' Contextual Performance (NCP) & 0.922 \\
\hline
\end{tabular}

\section{RESULTS}

\subsection{Factor Analysis for Job Resources Construct}

As indicated in Table 2, to assess the underlying structure of job resources and measure, 14 items were submitted to principle component method and varimax rotation analysis. The 14 items achieved more than 0.5 communalities and loaded on one factor. The KaiserMeyer-Olkin measures of sampling adequacy (KMO) for the single dimension solution was 0.98 , with chisquare of Bartlett's test of sphericity of 10210.22, degrees of freedom of 91.00 and was significant at 0.000 . The variance explained was $76.59 \%$ with extracted factors eigenvalue of more than 1 . This indicates that the data were suitable for factor analysis (Hair et al., 2010).

\subsection{Factor Analysis for Nurses' Performance Construct}

Nurses' performance construct dimensions were measured using 41 averaged items. A principle component factor analysis using varimax rotation was then conducted on the 41 items to determine which items should group to form what dimensions. The criteria developed by Igbaria et al. (1995) was used for cross loading, that is, a given item should load 0.50 or higher on a specific factor and have a loading no higher than 0.35 on other factors. Two items were deleted after applying this criterion. The KaiserMeyer-Olkin criterion was applied to extract the number of factors with only an eigenvalues equal or greater than one can be extracted (Kaiser, 1960). The output in Table 3 shows that the Kaiser-Meyer-Olkin measures of sampling adequacy (KMO) for the eight dimensions solution was 0.95 , with a significant Bartlett's Test of Sphericity (Sig $=0.000$ ). This indicates that the data were suitable for factor analysis (Hair et al., 2010). Hair et al. (2010) also stress that in social science research it is common to consider a solution that accounts for $60 \%$ or, in some instances, even less, of the total variance as satisfactory. In the present study, factor loading in the components met the criteria by Igbaria et al. (1995), that is, a given item should load 0.50 or higher on a specific factor and have a loading no higher than 0.35 on other factors. The result of factor analysis demonstrated eight factors with an eigenvalue of more than 1 . The results are presented in Table 4. 
Table 2. Summary of factor analysis of job resources construct $(n=632)$

\begin{tabular}{|c|c|c|c|c|c|}
\hline \multirow[b]{2}{*}{ Items } & \multicolumn{5}{|c|}{ Components } \\
\hline & 1 & 2 & 3 & 4 & 5 \\
\hline \multicolumn{6}{|l|}{ Factor 1: Job security } \\
\hline 1. I am presently safe from dismissal at this hospital. & 0.853 & -0.143 & -0.115 & -0.075 & -0.079 \\
\hline $\begin{array}{l}\text { 2. I am confident that this hospital will remain a steady place of } \\
\text { employment for as long as I want to continue working here. }\end{array}$ & 0.841 & -0.111 & -0.119 & -0.052 & -0.064 \\
\hline 3. I feel uneasy about the security in my present job. & 0.835 & -0.121 & -0.119 & -0.077 & -0.084 \\
\hline 4. I feel I am likely to be laid off at this hospital. & 0.842 & -0.100 & -0.086 & -0.084 & -0.091 \\
\hline 5. I am worried about my future with this hospital. & 0.847 & -0.152 & -0.088 & -0.069 & -0.133 \\
\hline 6. I am worried about my job security. & 0.848 & -0.108 & -0.113 & -0.060 & -0.125 \\
\hline \multicolumn{6}{|l|}{ Factor 2: Skill variety } \\
\hline $\begin{array}{l}\text { 1. My job requires me to do many different things as work, using a } \\
\text { variety of my skills and talents. }\end{array}$ & -0.159 & 0.758 & 0.105 & 0.085 & 0.189 \\
\hline 2. My job requires me to use a number of complex or high-level skills. & -0.126 & 0.718 & 0.027 & 0.070 & 0.244 \\
\hline 3. Overall, my tasks are not simple and repetitive. & -0.141 & 0.710 & 0.080 & 0.143 & 0.095 \\
\hline \multicolumn{6}{|l|}{ Factor 3: Feedback } \\
\hline $\begin{array}{l}\text { 1. My job itself provides me information about my work performance. That is, } \\
\text { the actual work itself provides clues about how well I am doing aside from any } \\
\text { feedback co-workers or supervisors may provide. }\end{array}$ & -0.158 & 0.144 & 0.795 & -0.028 & 0.196 \\
\hline 2. After I finish a task, I know whether I performed it well. & -0.152 & 0.109 & 0.818 & 0.029 & 0.075 \\
\hline $\begin{array}{l}\text { 3. Just doing the work required by this job provides many } \\
\text { chances for me to figure out how well I am doing. }\end{array}$ & -0.193 & 0.082 & 0.837 & 0.050 & 0.090 \\
\hline \multicolumn{6}{|l|}{ Factor 4: Task identity } \\
\hline $\begin{array}{l}\text { 1. My job is arranged so that I can usually do an entire } \\
\text { piece of work from beginning to end, not just a small } \\
\text { part of an overall piece of work. }\end{array}$ & -0.037 & 0.171 & 0.029 & 0.772 & 0.156 \\
\hline $\begin{array}{l}\text { 2. My job generally provides me the chance to completely } \\
\text { finish the pieces of work I begin. }\end{array}$ & -0.106 & 0.183 & 0.007 & 0.804 & 0.094 \\
\hline $\begin{array}{l}\text { 3. My job usually involves a complete piece of work that has } \\
\text { an obvious beginning and end. }\end{array}$ & -0.161 & 0.112 & 0.015 & 0.789 & 0.159 \\
\hline \multicolumn{6}{|l|}{ Factor 5: Task significance } \\
\hline $\begin{array}{l}\text { 1. My job is one where a lot of other people, in this hospital } \\
\text { and other hospitals, can be affected by how well my work gets done. }\end{array}$ & -0.189 & 0.231 & 0.158 & 0.180 & 0.744 \\
\hline $\begin{array}{l}\text { 2. My job is important in that the results of my work can } \\
\text { significantly affect other peoples' ability to do their work. }\end{array}$ & -0.220 & 0.258 & 0.126 & 0.192 & 0.729 \\
\hline $\begin{array}{l}\text { 3. My job itself is very significant and important } \\
\text { in that it facilitates or enables other peoples' work. }\end{array}$ & -0.126 & 0.207 & 0.141 & 0.141 & 0.774 \\
\hline Kaiser-Meyer-Olkin Measure of Sampling Adequacy. & \multicolumn{5}{|l|}{0.890} \\
\hline Bartlett's Test of Sphericity Approx. Chi-Square & \multicolumn{5}{|c|}{12808.520} \\
\hline df & \multicolumn{5}{|c|}{703.000} \\
\hline Sig. & \multicolumn{5}{|l|}{0.000} \\
\hline
\end{tabular}

\subsection{Reliability Analysis}

Reliability analysis was performed on the 13 dimensions extracted (i.e., skill variety, task significance, task identity, feedback, job security, job stress, organizational support, provision of information, coordination of care, provision of support, technical care, interpersonal support, job-task support, compliance and volunteering for additional duties). Cronbach's alpha coefficient was computed for each variable and presented in Table 4.

The results of the reliability of the measurement in this study appeared acceptable. Internal consistency of the scales ranged from 0.78 (skill variety) to 0.95 (job security), which suggest the specified indicators were sufficient for use (Hair et al., 2010). The result suggests that the variables were appropriate for further analysis. 
Table 3. Summary of factor analysis for nurses' performance construct $(\mathrm{N}=632)$

\begin{tabular}{|c|c|c|c|c|c|c|c|c|}
\hline \multirow[b]{2}{*}{ Items } & \multicolumn{8}{|c|}{ Components } \\
\hline & 1 & 2 & 3 & 4 & 5 & 6 & 7 & 8 \\
\hline \multicolumn{9}{|l|}{ Factor 1: Provision of information (Nurses' task performance) } \\
\hline 1. Explaining to patients what to expect when they leave the hospital. & 0.6410 & 0.208 & 0.127 & 0.169 & 0.148 & 0.203 & 0.053 & 0.157 \\
\hline 2. Providing instructions for care at home. & 0.7330 & 0.090 & 0.185 & 0.189 & 0.097 & 0.156 & 0.120 & 0.119 \\
\hline $\begin{array}{l}\text { 3. Explaining to families what to do if the patient's problems } \\
\text { or symptoms continue, get worse, or return. }\end{array}$ & 789.0000 & 0.123 & 0.200 & 0.135 & 0.069 & 0.121 & 0.057 & 0.157 \\
\hline $\begin{array}{l}\text { 4. Explaining to patients when they can resume normal activities, } \\
\text { such as going to work or driving a car. }\end{array}$ & 0.7890 & 0.142 & 0.133 & 0.124 & 0.108 & 0.057 & 0.043 & 0.087 \\
\hline $\begin{array}{l}\text { 5. Providing appropriate information to families } \\
\text { about nursing procedures performed. }\end{array}$ & 0.7300 & 0.204 & 0.187 & 0.100 & 0.193 & 0.091 & 0.110 & 0.053 \\
\hline 6. Communicating to patients the purpose of nursing procedures. & 0.6970 & 0.116 & 0.192 & 0.141 & 0.274 & 0.190 & 0.112 & 0.067 \\
\hline $\begin{array}{l}\text { 7. Informing patients of the possible side-effects of nursing procedure. } \\
\text { Factor 2: Job-task support (Nurses' contextual performance) }\end{array}$ & 0.657 & 0.101 & 0.012 & 0.152 & 0.250 & 0.325 & 0.063 & 0.092 \\
\hline 1. Making special arrangements for a patient's family. & 0.121 & 0.653 & 0.035 & 0.209 & 0.244 & 0.120 & 0.070 & 0.122 \\
\hline 2. Staying late to help families. & 0.128 & 0.814 & 0.048 & 0.071 & 0.119 & -0.048 & 0.010 & 0.042 \\
\hline 3. Taking extra time to respond to a family's needs. & 0.141 & 0.835 & 0.000 & 0.108 & 0.127 & 0.032 & 0.037 & 0.057 \\
\hline 4. Making special arrangements for the patient. & 0.171 & 0.641 & 0.142 & 0.186 & 0.113 & 0.151 & 0.172 & 0.237 \\
\hline 5. Staying late to help patients. & 0.147 & 0.600 & 0.174 & 0.210 & 0.003 & 0.039 & 0.286 & 0.089 \\
\hline $\begin{array}{l}\text { 6. Taking extra time to respond to a patient's needs. } \\
\text { Factor 3: Technical care (Nurses' task performance) }\end{array}$ & 0.142 & 0.614 & 0.206 & 0.202 & 0.075 & 0.020 & 0.181 & 0.164 \\
\hline 1. Taking patient observations (e.g. blood pressure, pulse, temperature). & 0.162 & -0.014 & 0.654 & 0.257 & 0.173 & 0.257 & 0.112 & 0.118 \\
\hline $\begin{array}{l}\text { 2. Assisting patients with activities of daily living } \\
\text { (e.g., showering, toileting and feeding). }\end{array}$ & 0.122 & 0.203 & 0.739 & 0.058 & 0.235 & 0.086 & 0.091 & 0.044 \\
\hline 3. Developing a plan of nursing care for patients. & 0.201 & 0.205 & 0.708 & 0.135 & 0.221 & 0.197 & 0.070 & 0.136 \\
\hline 4. Administering medications and treatments. & 0.228 & 0.006 & 0.791 & 0.219 & 0.094 & 0.181 & 0.073 & 0.145 \\
\hline 5. Evaluating the effectiveness of nursing care. & 0.231 & 0.133 & 0.744 & 0.193 & 0.146 & 0.121 & 0.080 & 0.162 \\
\hline \multicolumn{9}{|l|}{ Factor 4: Interpersonal support (Nurses' contextual performance) } \\
\hline 1. Raising morale of other nurses in the unit. & 0.271 & 0.189 & 0.091 & 0.660 & 0.162 & 0.156 & 0.123 & 0.204 \\
\hline 2. Helping nurses in the unit to resolve work problems. & 0.228 & 0.117 & 0.232 & 0.703 & 0.119 & 0.239 & 0.153 & 0.161 \\
\hline $\begin{array}{l}\text { 3. Consulting amongst each other when actions might } \\
\text { affect other nurses in the unit. }\end{array}$ & 0.154 & 0.206 & 0.254 & 0.705 & 0.106 & 0.163 & 0.130 & 0.072 \\
\hline 4. Taking time to meet unit nurses' emotional needs. & 0.089 & 0.257 & 0.127 & 0.708 & 0.244 & 0.000 & 0.106 & 0.084 \\
\hline $\begin{array}{l}\text { 5. Volunteering to share special knowledge or expertise } \\
\text { with other nurses in the unit. }\end{array}$ & 0.216 & 0.187 & 0.173 & 0.562 & 0.165 & 0.150 & 0.245 & 0.243 \\
\hline $\begin{array}{l}\text { 6. Helping nurses in the unit to catch up on their work. } \\
\text { Factor 5: Provision of support (Nurses' task performance) }\end{array}$ & 0.178 & 0.233 & 0.144 & 0.562 & 0.170 & 0.166 & 0.178 & 0.223 \\
\hline 1. Showing care and concern to families. & 0.251 & 0.120 & 0.246 & 0.314 & 0.625 & 0.172 & 0.064 & 0.115 \\
\hline 2. Listening to families' concerns. & 0.275 & 0.117 & 0.231 & 0.169 & 0.687 & 0.230 & 0.106 & 0.113 \\
\hline 3. Taking time to meet families' emotional needs. & 0.232 & 0.286 & 0.073 & 0.153 & 0.758 & 0.093 & 0.112 & 0.098 \\
\hline 4. Listening to patients' concerns. & 0.257 & 0.126 & 0.313 & 0.169 & 0.611 & 0.230 & 0.108 & 0.168 \\
\hline $\begin{array}{l}\text { 5. Taking time to meet the emotional needs of patients. } \\
\text { Factor 6: Coordination of care (Nurses' task performance) }\end{array}$ & 0.160 & 0.181 & 0.316 & 0.179 & 0.653 & 0.149 & 0.047 & 0.177 \\
\hline 1. Explaining to nurses in the unit the nature of the patient's condition. & 0.314 & 0.087 & 0.081 & 0.126 & 0.123 & 0.732 & 0.087 & 0.026 \\
\hline $\begin{array}{l}\text { 2. Reporting the critical elements of patients' situations when } \\
\text { turning over work shifts. }\end{array}$ & 0.147 & 0.067 & 0.241 & 0.199 & 0.105 & 0.774 & 0.125 & 0.027 \\
\hline $\begin{array}{l}\text { 3. Ensuring all members of the nursing unit are familiar } \\
\text { with the patient's recent medical history. }\end{array}$ & 0.191 & 0.099 & 0.174 & 0.073 & 0.198 & 0.769 & 0.088 & 0.099 \\
\hline $\begin{array}{l}\text { 5. Informing all nurses in the unit about patient tests and their results. } \\
\text { Factor 7: Compliance (Nurses' contextual performance) }\end{array}$ & 0.203 & -0.082 & 0.294 & 0.215 & 0.196 & 0.619 & 0.152 & 0.070 \\
\hline $\begin{array}{l}\text { 1. Complying with hospital rules, regulations } \\
\text { and procedures, even when no one is watching. }\end{array}$ & 0.048 & 0.096 & 0.172 & 0.208 & 0.056 & 0.140 & 0.772 & 0.096 \\
\hline 2. Representing the hospital favorably to individuals outside the hospital. & 1. 0.109 & 0.256 & 0.008 & 0.147 & 0.099 & 0.104 & 0.795 & 0.124 \\
\hline $\begin{array}{l}\text { 3. Making sure that materials and equipment are not wasted. } \\
\text { Factor 8: Volunteering for additional duties } \\
\text { (Nurses' contextual performance) }\end{array}$ & 0.187 & 0.132 & 0.119 & 0.168 & 0.121 & 0.119 & 0.744 & 0.165 \\
\hline $\begin{array}{l}\text { 1. Volunteering to participate on committees } \\
\text { within the hospital that are not compulsory. }\end{array}$ & 0.176 & 0.230 & 0.138 & 0.190 & 0.122 & 0.044 & 0.144 & 0.752 \\
\hline 2. Attending and participating in meetings regarding the hospital. & 0.198 & 0.212 & 0.181 & 0.192 & 0.193 & 0.091 & 0.166 & 0.736 \\
\hline $\begin{array}{l}\text { 3. Making innovative suggestions to improve the } \\
\text { overall quality of the department. }\end{array}$ & 0.168 & 0.128 & 0.188 & 0.245 & 0.150 & 0.067 & 0.135 & 0.771 \\
\hline Eigenvalues & 15.040 & 2.85 & 2.13 & 1.71 & 1.4 & 1.32 & 1.19 & 1.020 \\
\hline Percentage of Variance Explained $=68.50 \%$ & 12.350 & 9.82 & 9.63 & 9.25 & 7.96 & 7.51 & 6.00 & 5.980 \\
\hline Kaiser-Meyer-Olkin Measure of Sampling Adequacy & 0.950 & & & & & & & \\
\hline Bartlett's Test of Sphericity Approx. Chi-Square & 531.180 & & & & & & & \\
\hline$D f$ & 741.000 & & & & & & & \\
\hline Sig. & 0.000 & & & & & & & \\
\hline
\end{tabular}


Table 4. Cronbach's alphas of the study variables after factor analysis $(\mathrm{n}=632)$

\begin{tabular}{llll}
\hline No. of items & Variables & Alpha & Items dropped after factor analysis \\
\hline 4 & Skill Variety (SV) & 0.78 & - \\
3 & Task Significance (TS) & 0.82 & - \\
3 & Task Identity (TI) & 0.78 & - \\
3 & Feedback (FB) & 0.82 & - \\
6 & Job security (JSec) & 0.95 & - \\
7 & Provision of Information (PI) & 0.91 & - \\
4 & Coordination of Care (CC) & 0.85 & 1 \\
5 & Provision of Support (PS) & 0.89 & 1 \\
5 & Technical Care (TC) & 0.89 & - \\
6 & Interpersonal support (IntSup) & 0.88 & - \\
6 & Job-Task support (J-TSup) & 0.86 & - \\
3 & Compliance (Com) & 0.81 & - \\
3 & Volunteering for Additional Duties (VAD) & 0.85 & - \\
\hline
\end{tabular}

\section{DISCUSSION}

\subsection{Descriptive Analysis}

The general statistical description of variables used in this study was examined by using descriptive analysis. Statistical values of means, standard deviation, minimum and maximum were calculated for the independent variables, the mediating variable, the moderating variable and the dependent variable. The results of these statistical values are shown in Table $\mathbf{5}$.

Table 5 presents the summary of means of the independent variables, mediating variable, moderating variable and dependent variables. The mean for all variables was between 1.27 and 3.97. In general, close to half of the variables $(47.37 \%)$ had moderate mean values between 2.34 and 3.67 (skill variety, feedback, job security, provision of information, provision of support, job-task support and volunteering for additional duties). On the other hand, $31.58 \%$ of the variables had mean values of more than 3.67 (task significance, task identity, coordination of care, technical care, interpersonal support and compliance) and $21.05 \%$ had low mean values of less than 2.34 (quantitative demands, physical demands, emotional demands and shift work). Technical care had the highest mean of 3.97 with a standard deviation of 0.78 and minimum and maximum scores of 1.80 and 5.00, respectively, while shift work scored the lowest mean of 1.27 with a standard deviation of 0.43 and minimum and maximum scores of 1.00 and 2.00, respectively.

\subsection{Effect of Job Resources on Nurses' Performance (Task and Contextual)}

This study requires an analysis to examine the relationship between the independents variables of job resources, namely skill variety, task significance, task identity, feedback, job security and the dependent variables of nurses' performance namely nurses' task and contextual performance (i.e., provision of information, coordination of care, provision of support, technical care, interpersonal support, job-task support, compliance and volunteering for additional duties).

A standard multiple regression analysis was conducted. The study used an "enter" method to perform the regression analysis. The multiple correlation (R), squared multiple correlation $\left(\mathrm{R}^{2}\right)$ and adjusted squared multiple correlation $\left(\operatorname{adj} R^{2}\right)$ indicate how well the combination of the independent variables predict the dependent variable is shown in Table 6.

The main purpose of the present study was to examine the determinants of job performance among nurses in public hospitals in the Kingdom of Saudi. Specifically, the study examined the direct relationship of job demands (i.e., physical demands, emotional demands, quantitative demands and shift work) and nurses' job performance. Towards this end, a number of research hypotheses were formulated. In general, the present study has provided empirical support for the determinants of nurses' job performance.

The present study hypothesized that job demands affect nurse's performance in public hospitals in Saudi Arabia. Job demands in the present study refer to "those 
physical, psychological, social, or organizational aspects of the job that require sustained physical or psychological (cognitive and emotional) effort or skills and are therefore associated with certain physiological or psychological costs" (Demerouti et al., 2001). In the present study, job demands were operationalized by four dimensions of quantitative demands, physical demands, emotional demands and shift work. Job resources, in the present study, was defined as "those physical, psychological, social, or organizational aspects of the job that (a) are functional in achieving work goals; (b) reduce job demands and the associated physiological and psychological costs; or (c) stimulate personal growth, learning and development" (Demerouti et al., 2001). Here, skill variety, task significance, task identity, feedback and job security were employed to measure job resources.

The negative relationship between job demands and job (task and contextual) performance of nurses is expected because according to job demands-resources model, when demands are high (e.g., quantitative demands and physical demands) it may not be easy for employees to allocate their attention and energy efficiently because they have to engage in greater activation and/or effort and this, in turn, negatively affects their performance (Bakker et al., 2004). Furthermore, Peters et al. (2009) found that nurses working in nursing and care homes reported job demands to negatively affect their job performance.

Table 5. Mean, standard deviation, minimum and maximum of job resources and nurses' (Task and Contextual) Performance $(\mathrm{N}=$ 632)

\begin{tabular}{|c|c|c|c|c|}
\hline Variables & Mean & $\mathrm{SD}$ & Minimum & Maximum \\
\hline$\overline{\text { Skill Variety }(\mathrm{SV})^{\mathrm{e}}}$ & 3.46 & 0.87 & 1.50 & 5.00 \\
\hline Task Significance $(\mathrm{TS})^{\mathrm{e}}$ & 3.73 & 0.84 & 2.00 & 5.00 \\
\hline Task Identity (TI) ${ }^{\mathrm{e}}$ & 3.74 & 0.63 & 2.67 & 4.67 \\
\hline Feedback $(F B)^{\mathrm{e}}$ & 3.53 & 0.86 & 1.33 & 5.00 \\
\hline Job security $(\mathrm{JSec})^{\mathrm{e}}$ & 2.64 & 1.28 & 1.00 & 5.00 \\
\hline Provision of information $(\mathrm{PI})^{\mathrm{g}}$ & 3.45 & 0.79 & 1.57 & 5.00 \\
\hline Coordination of Care $(\mathrm{CC})^{\mathrm{g}}$ & 3.82 & 0.80 & 1.60 & 5.00 \\
\hline Provision of Support (PS) ${ }^{\mathrm{g}}$ & 3.60 & 0.79 & 1.40 & 5.00 \\
\hline Technical Care (TC) ${ }^{\mathrm{g}}$ & 3.97 & 0.78 & 1.80 & 5.00 \\
\hline Interpersonal support $(\operatorname{IntSup})^{\mathrm{h}}$ & 3.73 & 0.82 & 1.50 & 5.00 \\
\hline Job-task support $(\text { JTSup })^{\mathrm{h}}$ & 3.24 & 0.78 & 1.33 & 5.00 \\
\hline Compliance $(\mathrm{Com})^{\mathrm{h}}$ & 3.72 & 0.84 & 1.67 & 5.00 \\
\hline Volunteering for Additional Duties (VAD) ${ }^{\mathrm{h}}$ & 3.62 & 0.84 & 1.33 & 5.00 \\
\hline
\end{tabular}

Note; ${ }^{\mathrm{a}} 1$ = hardly ever, $2=$ seldom, $3=$ a few times, $4=$ many times, $5=$ always; ${ }^{\mathrm{b}} 1=0-1$ time a day, $2=2-4$ times a day, $3=5-7$ times a day, $4=8$-10 times a day, $5=>10$ times a day; ${ }^{\mathrm{c}} 1=$ never, $2=$ seldom, $3=$ sometimes, $4=$ often, $5=$ always; ${ }^{\mathrm{d}} 1=$ not at all, 2 $=\mathrm{a}$ few times, $3=$ sometimes, $4=$ quite a lot, $5=$ a great deal; ${ }^{\mathrm{e}} 1=$ strongly disagree, $2=$ disagree, $3=$ neutral, $4=$ agree, $5=$ strongly agree; ${ }^{\mathrm{f}} 1=$ none of the time, $2=$ a little bit of time, $3=$ some of the time, $4=$ a lot of the time, $5=$ all of the time; ${ }^{\mathrm{g}} 1=$ Much below average, $2=$ Somewhat below average, $3=$ Average, $4=$ Somewhat above average, $5=$ Much above average; ${ }^{\mathrm{h}} 1=$ not at all, 2 $=$ minimally, $3=$ somewhat, $4=$ quite a bit, $5=$ a great deal

Table 6. Multiple Regression Analysis: Job resources and nurses' task performance and contextual performance $(\mathrm{n}=632)$

\begin{tabular}{|c|c|c|c|c|c|c|c|c|}
\hline \multirow[b]{3}{*}{$\begin{array}{l}\text { Independent } \\
\text { variables }\end{array}$} & \multicolumn{8}{|c|}{ Standardized beta } \\
\hline & \multicolumn{5}{|c|}{ Task performance } & \multicolumn{3}{|c|}{ Contextual performance } \\
\hline & $\begin{array}{l}\text { Provision of } \\
\text { information }\end{array}$ & $\begin{array}{l}\text { Coordination } \\
\text { of care }\end{array}$ & $\begin{array}{l}\text { Provision of } \\
\text { support }\end{array}$ & $\begin{array}{l}\text { Technical } \\
\text { care }\end{array}$ & $\begin{array}{l}\text { Interpersonal } \\
\text { support }\end{array}$ & $\begin{array}{l}\text { Job-Task } \\
\text { support }\end{array}$ & Compliance & $\begin{array}{l}\text { Volunteering for } \\
\text { Additional Duties) }\end{array}$ \\
\hline Job Variety (JV) & $0.210 * *$ & $0.195 * *$ & $0.208 * *$ & $0.234 * *$ & $0.193 * *$ & $0.139 * *$ & $0.145^{* *}$ & $0.199 * *$ \\
\hline Task Significance (TS) & $0.309 * *$ & $0.243 * *$ & $0.280 * *$ & $0.268 * *$ & $0.337 * *$ & $0.329 * *$ & $0.149 * *$ & $0.242 * *$ \\
\hline Task Identity (TI) & $0.160 * *$ & 0.03 & $0.202 * *$ & $0.127 * *$ & $0.232 * *$ & $0.233 * *$ & $0.145^{* *}$ & $0.162 * *$ \\
\hline Feedback (FB) & $0.149 * *$ & $0.201 * *$ & $0.113 * *$ & $0.122 * *$ & $0.099 * *$ & 0.008 & $0.110 * *$ & $0.118 * *$ \\
\hline Job Security (JS) & $0.198 * *$ & $0.177 * *$ & $0.089 *$ & 0.034 & $0.097 * *$ & $0.113 * *$ & 0.076 & $0.110 * *$ \\
\hline F value & 44.17 & 31.86 & 47.78 & 41.09 & 65.16 & 29.79 & 18.53 & 35.88 \\
\hline $\mathrm{R}^{2}$ & 0.390 & 0.316 & 0.409 & 0.373 & 0.485 & 0.301 & 0.211 & 0.342 \\
\hline Adjusted $\mathrm{R}^{2}$ & 0.381 & 0.306 & 0.400 & 0.364 & 0.478 & 0.291 & 0.200 & 0.332 \\
\hline Durbin Watson & 1.840 & 1.870 & 1.980 & 1.860 & 1.750 & 1.850 & 1.850 & 1.760 \\
\hline
\end{tabular}

Note: ${ }^{*} \mathrm{p}<0.05,{ }^{*} \mathrm{p}<0.01$ 


\section{CONCLUSION}

This study has investigated the factors influencing nurses' job performance among the Ministry of Health hospitals in Saudi Arabia using job demands and resources model based on Conservation of Resources theory (COR), social exchange theory and negative linear theory that may help nurses' managers to realize nurses' performance behavior. The findings showed that the nurses' job performance can be modeled by the job Demands and Resources (JD-R) model original constructs in addition to other significant variables derived from other related theories. The present research model was tested and validated with 632 hospitals nurses in one region in Saudi Arabia. The study on the factors affecting the hospitals nurses in Saudi Arabian Ministry of Health was deemed necessary in order to increase the nurses' job performance.

The study found the level of nurses' job performance among hospitals nurses in Saudi Arabia to be moderate. Also the study found direct significant relationships among the tested job demands and resources variables with nurses' job performance. Moreover, the study found partial support for the role of job stress as a mediator in a relationship between Job Demands and Resources (JDR) and nurses' job performance. Job stress mediated the relationship between job demands and resources variables (except job security) and two dimensions of job contextual performance (compliance and volunteering for additional duties).

\section{REFERENCES}

Bakker, A.B. and E. Demerouti, 2007. The job demandsresources model: State Art. J. Managerial Psychol., 22: 309-328. DOI: 10.1108/02683940710733115

Bakker, A.B. and M.P. Bal, 2010. Weekly work engagement and performance: A study among starting teachers. J. Occupat. Organ. Psychol., 83: 189-206. DOI: 10.1348/096317909X402596

Bakker, A.B., E. Demerouti and W. Verbeke, 2004. Using the job demands-resources model to predict burnout and performance. Hum. Res. Manage., 43: 83-104. DOI: $10.1002 / \mathrm{hrm} .20004$

Bakker, A.B., E. Demerouti, T.W. Taris, W.B. Schaufeli and P.J.G. Schreurs, 2003. A multigroup analysis of the job demands-resources model in four home care organizations. Int. J. Stress Manage., 10: 16-38. DOI: $10.1037 / 1072-5245.10 .1 .16$
Bono, J.E. and T.A. Judge, 2003. Self-concordance at work: Toward understanding the motivational effects of transformational leaders. Acad. Manage. J., 46: 554-571. DOI: 10.2307/30040649

Borg, I. and D. Elizur, 1992. Job insecurity: Correlates, moderators and measurement. Int. J. Manpower, 13: 13-26. DOI: 10.1108/01437729210010210

Bowen, D.E. and E.E. Lawler, 1992. The empowerment of service workers: What, why, how and when. Sloan Manage. Rev., 33: 31-39. PMID: 10118526

Conger, J.A. and R.N. Kanungo, 1988. The empowerment process: Integrating theory and practice. Acad. Manage. Rev., 13: 471-482. DOI: 10.5465/AMR.1988.4306983

Cooper, D.R. and P.S. Schindler, 2008. Business Research Methods. 10th Edn., McGraw-Hill Higher Education, Boston, ISBN-10: 0071263330, pp: 746.

De Jonge, J. and C. Dormann, 2006. Stressors, resources and strain at work: A longitudinal test of the triplematch principle. J. Applied Psychol., 91: 1359-1374. DOI: 10.1037/0021-9010.91.5.1359

Demerouti, E., A.B. Bakker, F. Nachreiner and W.B. Schaufeli, 2001. The job demands-resources model of burnout. J. Applied Psychol., 86: 499-512. DOI: 10.1037/0021-9010.86.3.499

Demerouti, E., A.B. Bakker, F. Nachreiner and W.B. Schaufeli, 2000. A model of burnout and life satisfaction amongst nurses. J. Adv. Nurs., 32: 454464. DOI: 10.1046/j.1365-2648.2000.01496.x

Erez, A. and T.A. Judge, 2001. Relationship of core selfevaluations to goal setting, motivation and performance. J. Applied Psychol., 86: 1270-1279. DOI: $10.1037 / 0021-9010.86 .6 .1270$

Fullagar, C.J. and E.K. Kelloway, 2009. Flow at work: An experience sampling approach. J. Occupat. Organ. Psychol., 82: 595-615. DOI: 10.1348/096317908X357903

Garg, P. and R. Rastogi, 2006. New model of job design: Motivating employees' performance. J. Manage. Dev., 25: 572-587. DOI: $10.1108 / 02621710610670137$

Goldenhar, L.M., A.D. LaMontagne, T. Katz, C. Heaney and P. Landsbergis, 2001. The intervention research process in occupational safety and health: An overview from the national occupational research agenda intervention effectiveness research team. J. Occupat. Environ. Med., 43: 616-622. DOI: 10.1097/00043764-200107000-00008 
Graham, S., 2009. The effects of different conflict management styles on job satisfaction in rural healthcare settings. Econ. Bus. J. Inquiries Perspectives, 2: 71-85.

Hackman, J.R. and G.R. Oldham, 1980. Work Redesign. 1st Edn., Addison-Wesley, Reading, ISBN-10: 0201027798, pp: 330.

Hair, J.F., W.C. Black, B.J. Babin and R.E. Anderson, 2010. Multivariate Data Analysis. 7th Edn., Prentice Hall Higher Education, Upper Saddle River, NJ., New York, ISBN-10: 0138132631, pp: 785.

Igbaria, M., J. Iivari and H. Maragahh, 1995. Why do individuals use computer technology? A Finnish case study. Inform. Manag., 29: 227-238. DOI: 10.1016/0378-7206(95)00031-0

Ito, J.K. and C.M. Brotheridge, 2007. Exploring the predictors and consequences of job insecurity's components. J. Managerial Psychol., 22: 40-64. DOI: $10.1108 / 02683940710721938$

Kaiser, H.F., 1960. The application of electronic computers to factor analysis. Educ. Psychol. Measur., 20 : $141-151 . \quad$ DOI: 10.1177/001316446002000116

Kinnunen, U., T. Feldt and A. Makikangas, 2008. Testing the effort-reward imbalance model among Finnish managers: The role of perceived organizational support. J. Occupat. Health Psychol., 13: 114-127. DOI: 10.1037/1076-8998.13.2.114

Lee, H., J.E. Wilbur, M.J. Kim and A.M. Miller, 2008. Psychosocial risk factors for work-related musculoskeletal disorders of the lower-back among long-haul international female flight attendants. J. Adv. Nurs., 61: 492-502. DOI: 10.1111/j.13652648.2007.04511.x

Lim, V.K.G. and T.S.H. Teo, 2000. To work or not to work at home-an empirical investigation of factors affecting attitudes towards teleworking. J. Managerial Psychol., 15: 560-586. DOI: 10.1108/02683940010373392

Lin, S.L. and A.T. Hsieh, 2002. Constraints of task identity on organizational commitment. Int. J. Manpower, 23: 151-165. DOI: 10.1108/01437720210428405

Mehta, V. and H. Shah, 2005. Characteristics of a work organization from a lean perspective. Eng. Manage. J., 17: 14-20.

Mikkelsen, A., T. Ogaard and N. Lovrich, 2000. Modeling the effects of organizational setting and individual coping style on employees subjective health, job satisfaction and commitment. Public Admin. Q., 24: 371-397.
Neuman, W.L., 1997. Social Research Methods: Qualitative and Quantitative Approaches. 3rd Edn., Allyn and Bacon, Boston, ISBN-10: 0205193560, pp: 560.

Nunnally, J.C., 1978. Psychometric Theory. 1st Edn., Tata McGraw-Hill Education, ISBN-10: 0071070885, pp: 752.

Peters, V.P.J.M., A.E. De Rijk and N.P.G. Boumans, 2009. Nurses' satisfaction with shiftwork and associations with work, home and health characteristics: A survey in the Netherlands. J. Adv. Nurs., 65: 2689-2700. DOI: 10.1111/j.13652648.2009.05123.x

Rothmann, S. and J.H.M. Joubert, 2007. Job demands, job resources, burnout and work engagement of managers at a platinum mine in the North West Province. South African J. Bus. Manage., 38: 4961.

Schmidt, F.L. and J.E. Hunter, 1998. The validity and utility of selection methods in personnel psychology: Practical and theoretical implications of 85 years of research findings. Psychol. Bull., 124: 262-274. DOI: 10.1037/0033-2909.124.2.262

Van Emmerik, I.J.H. and M.C.W. Peeters, 2009. Crossover specificity of team-level work-family conflict to individual-level work-family conflict. J. Managerial Psychol., 24: 254-268. DOI: 10.1108/02683940910939331

Wiley, C., 1997. What motivates employees according to over 40 years of motivation surveys. Int. J. Manpower, 18: 263-280. DOI: 10.1108/01437729710169373

Yahaya, N., A. Yahaya, F.F. Tamyes, J. Ismail and S. Jaalam, 2010. The effect of various modes of occupational stress, job satisfaction, intention to leave and absentism companies commission of Malaysia . Australian J. Basic Applied Sci., 4: 16761684.

Zikmund, W.G., B.J. Babin, J.C. Carr and M. Griffin, 2010. Business Research Methods Canada: SouthWestern. 1st Edn., Cengage Learning, Mason, ISBN-10: 1111826927 , pp: 696. 